\title{
Impact of Climate Change on Rice Production and Local Adaptation Practices Adopted by Farmers in Surkhet, Nepal
}

\author{
Bakhat Bahadur Khadka $^{1 *}$, Hridesh Sharma ${ }^{2}$, Ananta Prakash Subedi ${ }^{3}$, Shiva Chandra Dhakal ${ }^{3}$ \\ ${ }^{1}$ Ministry of Land Management, Agriculture and Co-operative-Karnali province, Nepal \\ ${ }^{2} \mathrm{SAFBIN}$ project-Caritas Nepal, \\ ${ }^{3}$ Agriculture and Forestry University- Chitwan, Nepal
}

Article Information
Received: 07 July 2020
Revised version received: 15 October 2020
Accepted: 18 October 2020
Published: 29 October 2020
Cite this article as:
B.B. Khadka et al. (2020) Int. J. Soc. Sc. Manage.
7(4): $202-213$. DOI: $10.3126 /$ ijssm.v7i4.32472
*Corresponding author
Bakhat Bahadur Khadka,
Ministry of Land Management, Agriculture and Co-
operative-Karnali province, Nepal
Email: bbkhadka13@gmail.com
Peer reviewed under authority of IJSSM
C 2020 IJSSM, Permits unrestricted use under the
CC-By-NC license.
OPEN 0 ACCESS
This is an open access article \& it is licensed under a
Creative Commons Attribution Non-Commercial 4.0
https://creativecommons.org/licenses/by-nc/4.0/)

\begin{abstract}
A total of 120 sample households were randomly selected from two municipalities of Surkhet for this study. The primary data were collected by survey questionnaire, direct observation, FGD whereas secondary data of rainfall temperature and rice productivity were collected from different sources. Majority of farmers perceived increase in temperature, decrease in rainfall frequency, decrease in rainfall duration and increase in flooding hazard during rainy season. Trends analysis of temperature and rainfall data over 35 years (1980-2015) showed, increasing trends of maximum temperature $\left(0.06^{\circ} \mathrm{C} /\right.$ year $)$ and minimum temperature $\left(0.03^{\circ} \mathrm{C} /\right.$ year $)$ which were in the line with the farmer's perception. Trend analysis revealed that total annual precipitation was decreasing by $3.77 \mathrm{~mm} / \mathrm{year}$ while monsoon rainfall was increasing by $0.051 \mathrm{~mm} /$ year. About $20 \%$ respondents had clear knowledge on climate change. The major source of information was media $(43.43 \%)$ and selfexperiences $(36.3 \%)$. The major climate change adaptation practices adopted by farmers were use of drought resistant varieties, flood resistant varieties, use of electric water pump, and use of local irrigation channel. The study showed that only $39.17 \%$ of the respondents know about crop insurance policy and only $6.66 \%$ of the total respondents done crop insurance on different crop. The regression analysis showed that rainfall and average maximum temperature has positive effect on yield and production. The study showed that farmers were positive to adapt climate change adaptation strategies. So, government and policy makers should focus on climate resilient adaptation strategies formulation for rice cultivation through intensive research and extension package.
\end{abstract}

Keywords: Climate Change; Rice production; Adaptation

\section{Introduction}

Climate change and global warming are the great concern of today as they affect the natural ecosystem. Climate change refers to variation in the global climate or regional climate over long time period. Increase in concentration of greenhouse gases (GHGs) mainly $\mathrm{CO}_{2}, \mathrm{~N}_{2} \mathrm{O}$ and $\mathrm{CH}_{4}$ in atmosphere due to natural as well as anthropogenic factors is causing climate change (IPCC, 2007) affecting the agriculture, human health, forestry, biodiversity, aquatic, terrestrial and mountain ecosystem which has been burning issue of discussion and debate in recent decades. Exponential increasing in Carbon dioxide $\left(\mathrm{CO}_{2}\right)$ concentration, which contributes more than $80 \%$ of total GHGs emission causes greenhouse effects (Malla, 2008). Nepal's contribution to the global greenhouse gases emission is $0.025 \%$ (Oli \& Shrestha, 2009). Climate change is an emerging environmental challenge, which has been considered through several basic indicators such as 
increased temperature, variability and uncertainty of precipitation. Extreme weather condition such as heat waves, drought, floods, erratic and inconsistent rainfall, change in crop production pattern, rise in sea level, polar ice and glacier melting, increase in infestation of disease and pest are some of incidences likely to happen due to climate change (IPCC, 2007).

Climate is one of the major determinants for agricultural production and productivity. Temperature, solar radiation, rainfall, soil moisture and $\mathrm{CO}_{2}$ concentration are all important climatic variables that determine agricultural productivity. It is major concern about the impact of climate change on agricultural system as agriculture is highly vulnerable to climate change, which is more complex and not linear relationship. The impact of climate change as witnessed in recent times has adversely affected agriculture in various ways. Higher temperature beyond optimum range eventually reduce crop yield due to higher respiration and increased development rates while encouraging the proliferation of disease, pest and weed. The average temperature increased by $0.06^{\circ} \mathrm{C}$ per annum (Maraseni, 2012) in Nepal. Variation and uncertainty of rainfall increase leads to crop failure. Moreover, the overall climate change impact on agriculture sector is expected to be negative even though there may be positive effect on some crops in some region of the world, threatening the global food security (Malla, 2008).

Nepal is a small mountainous landlocked agrarian country in South Asia with area of 147, 181 sq. km and located between latitude of $26^{\circ} 22^{\prime}$ to $30^{\circ} 27^{\prime}$ north and longitude $80^{\circ} 04^{\prime}$ to $88^{\circ} 12^{\prime}$ east. Nepal is the fourth most vulnerable country for climate change (Panthi et al., 2016) and very sensitive to small changes in climatic variables. About 1.9 million people are vulnerable \& 10 million exposed to increasing risk due to climate change in Nepal (MoE, 2010). The agriculture sector accounts for $33 \%$ of total Gross
Domestic Product (GDP) and 65.6\% of Nepal's population is engaged in agriculture (MoAD, 2012). Nepal's agriculture is largely rain fed and over $50 \%$ of Nepalese farmers are small holders cultivating less than 0.5 ha (CBS, 2011). Rice is the major and most prestigious food crop in Nepal. It is grown in diverse environment from tropical plain region to foot of mountain up to highest elevation (3050 masl). It contributes nearly $20 \%$ to the agricultural gross domestic product (AGDP) and provides more than $50 \%$ of the total calorie requirement of the Nepalese people (MoAD, 2014).

\section{Objectives}

The broad objective of this study is to assess impact of climate change, farmers perception and adaptation measures adopted by farmers to cope with adverse impact of climate change in Surkhet of Nepal.

\section{Specific Objectives}

- To assess the farmer's perception on climate change in the study area.

- To analyze the trends of climate change and its impacts on rice production and productivity.

- To document the local adaptation practices adopted by farmer to cope with climate change.

\section{Materials and Methods}

Purposively two municipality was selected upon the discussion with District Agriculture Development Office (DADO), Surkhet. Two wards per municipality were randomly selected. During the selection of the respondent at least 10 years of settlements within this locality were included in the sample, because they provide valuable and useful information regarding the past trends on climatic variables. Altogether 120 rainy season rice cultivating respondents, 60 households from each municipality were selected through stratified random sampling method for this study as shown in Fig. 1.

\section{Sampling Procedure for the study}

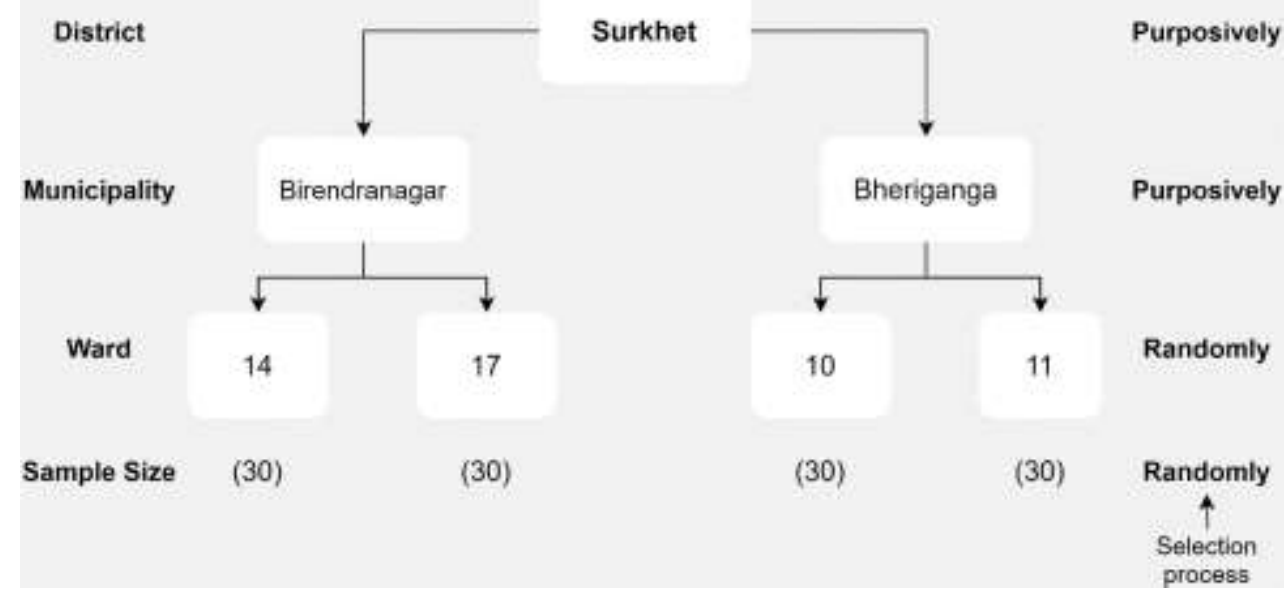

Fig. 1: Sampling procedure for the study 
Primary data and secondary data were collected for this study. Household visit and interview method was used for data collection for primary data collection. Those households were selected randomly and triangulated the data conducting one FGD on each village also verified by KII with DADO, Agriculture Service Center (ASC) and personnel. Secondary data were collected from DADO, ASC and Department of Hydrology and Meteorology (DHM). The collected data were coded, tabulated and analyzed by using Statistical Package for Social Science (SPSS), MS Excel and STATA.

\section{Regression Analysis}

Time series model is most used and appropriate to access the impact of climate change on rice production and productivity. The analysis was done in SPSS (16 version) by using time series data of climatic variables (Rainfall and temperature) and rice yield and production of 15 years that are taken from different secondary data sources. Rice growing period for Surkhet is June to November. Climate data of rice growing period was considered during regression analysis. Linear specification models are applied to gauge impact of climatic variables on rice yield and production due to lack of longitudinal cross-sectional data within a mentioned period (equation 1).

$Y_{t}=\beta_{0}+\beta_{1} T \max _{t}+\beta_{2} T \min _{t}+\beta_{3} \operatorname{Rain}_{t}+\gamma D D+\varepsilon_{t}$ Eq 1

Where,

$\mathrm{Yt}=$ Annual rice production $(\mathrm{Mt})$

Raint $=$ Average rice grown seasonal rainfall $(\mathrm{mm})$

Tmax =Average rice grown seasonal maximum temperature $\left({ }^{\circ} \mathrm{C}\right)$

Tmin = Average rice grown seasonal minimum temperature $\left({ }^{\circ} \mathrm{C}\right)$

$\mathrm{DD}=$ District fixed effect

$\varepsilon=$ Error term

$$
\mathrm{t}=\text { Years }
$$

\section{Results and Discussions}

\section{Socio-Economic and Demographic Information of The Respondents}

Population Characteristics of Respondents by Age Group Identification of the respondents according to age group is very important because old age person have good knowledge about climate change trends and they are the better source of required information. In this study, out of the 120 respondents, majority of them $(50 \%)$ were in the range of 35-60 years followed by the age group below 35 $(34.2 \%)$ and above 60 years (19\%) as shown in Table 1.
The study revealed that most of the respondents were Male $(50.83 \%)$ across the study site with $49.17 \%$ being female as shown in Table 2.

Table 1: Distribution of respondent by age group on July 2016

\begin{tabular}{lll}
\hline \multirow{2}{*}{ Age group } & \multicolumn{2}{c}{ Age of respondents } \\
\cline { 2 - 3 } & Frequency & Percentage \\
\hline$<35$ & 41 & 34.2 \\
$35-60$ & 60 & 50 \\
$>60$ & 19 & 15.8 \\
\hline Total & 120 & 100 \\
\hline
\end{tabular}

Table 2: Distribution of respondents by sex on July 2016

\begin{tabular}{|c|c|c|c|}
\hline \multirow{2}{*}{$\begin{array}{l}\text { Sex of } \\
\text { respondent }\end{array}$} & \multicolumn{2}{|c|}{ Municipality } & \multirow{2}{*}{ Total } \\
\hline & $\begin{array}{l}\text { Birendra } \\
\text { Nagar }\end{array}$ & Bheriganga & \\
\hline Female & $24(40)$ & $35(58.3)$ & $59(49.17)$ \\
\hline Male & $36(60)$ & $25(41.7)$ & $61(50.83)$ \\
\hline Total & $60(100.0)$ & $60(100.0)$ & $120(100.0)$ \\
\hline
\end{tabular}

\section{Educational Level of Respondents}

Education plays a vital role in socio- cultural and economic change in a society. To assess the educational status of respondents, six categories, namely illiterate (who cannot read and write), Literate (who gain informal education and can only read and write), primary (formal education up to five), secondary (up to ten), higher secondary (up to twelve) and graduate/university, of education group was formed. Most of the respondents were found to be literate (49.3\%) followed by secondary (49\%), primary $(27.3 \%)$, Illiterate $(26.7 \%)$, higher secondary $(6 \%)$ and university $(1.7 \%)$ as shown in Table 3.

Table 3: Distribution of respondents by education level on July 2016

\begin{tabular}{llll}
\hline \multirow{2}{*}{$\begin{array}{l}\text { Educational } \\
\text { level }\end{array}$} & \multicolumn{3}{c}{ Municipality } \\
\cline { 2 - 3 } & $\begin{array}{l}\text { Birendra } \\
\text { Nagar }\end{array}$ & Bheriganga & Total \\
\hline $\begin{array}{l}\text { illiterate } \\
\text { Literate }\end{array}$ & $13(21.7)$ & $5(8.3)$ & $18(26.7)$ \\
Primary & $8(13.3)$ & $14(23.3)$ & $22(27.3)$ \\
Secondary & $18(30)$ & $19(31.7)$ & $37(49)$ \\
Higher & $3(5)$ & $1(1.7)$ & $4(6)$ \\
secondary & $1(1.7)$ & $0(0)$ & $1(1.7)$ \\
University & $60(100.0)$ & $60(100.0)$ & $120(100$ \\
\hline Total & & & $.0)$ \\
\hline
\end{tabular}

Figure in the parenthesis indicate percentage

Sex of the Respondents 


\section{Household and Farm Characteristics in The Study Area}

Ethnicity of The Respondent's Household

In the study area, majority of the respondents were Aadibasi/Janajati and Chhetri followed by Dalit, Brahmin and Others. Out of 120 the respondents, $47.5 \%$ were Aadibasi/Janajati followed by Chhetri (28.333\%), Dalit (11.67\%), Brahmin $(8.33 \%)$ and others $(4.16 \%)$. In the Birendra Nagar Municipality, majority of the respondents were Janajati (60\%) whereas, in Bheriganga, majority of the respondents were Chhetri (36.7\%). Distribution of respondents in the study area is presented in Table 4.

Table 4: Distribution of survey household by ethnicity on July 2016

\begin{tabular}{llll}
\hline \multirow{2}{*}{ Ethnicity } & \multicolumn{3}{c}{ Municipality } \\
\cline { 2 - 3 } & $\begin{array}{l}\text { Birendra } \\
\text { Nagar }\end{array}$ & Bheriganga & \\
\hline Brahmin & $8(13.3)$ & $2(3.3)$ & $10(8.33)$ \\
Chhetri & $12(20)$ & $22(36.7)$ & $34(28.33)$ \\
Dalit & $1(1.7)$ & $13(21.7)$ & $14(11.67)$ \\
Adibasi/Janajati & $36(60)$ & $21(35)$ & $57(47.5)$ \\
Others & $3(5)$ & $2(3.3)$ & $5(4.167)$ \\
\hline Total & $60(100.0)$ & $60(100.0)$ & $120(100.0)$
\end{tabular}

Figure in the parenthesis indicate percentage

\section{Primary Occupation of The Respondent}

Occupation of local community people reflect the nature of micro-economy of any locality and various commercial, business as well as employment opportunity in the area and also determines the well -being of living standard. The study revealed that majority of the households primary occupation was Agriculture (86.67\%) contributed by $85 \%$ from Birendra Nagar and $88.3 \%$ from Bheriganga. Percentage of households involved in service was $8.33 \%$ followed by business $5 \%$ as shown in Table 5.

Table 5: Primary occupation of the household on July 2016

\begin{tabular}{llll}
\hline \multirow{2}{*}{ Ethnicity } & \multicolumn{2}{c}{ Municipality } & Total \\
\cline { 2 - 3 } & $\begin{array}{l}\text { Birendra } \\
\text { Nagar }\end{array}$ & Bheriganga & \\
\hline Agriculture & $51(85)$ & $53(88.3)$ & $104(86.67)$ \\
Service & $4(6.7)$ & $6(10)$ & $10(8.33)$ \\
Business & $5(8.3)$ & $1(1.7)$ & $6(5)$ \\
\hline Total & $60(100.0)$ & $60(100.0)$ & $120(100.0)$ \\
\hline
\end{tabular}

Figure in the parenthesis indicate percentage

Gender of The Population in Study Site

Total population of the 120 sampled households was 659 .

Among them, 49.77 percent were male and 50.23 percent were female. In Birendra Nagar, percentage of Male
$(50.74 \%)$ was higher than female (49.26), whereas, In Bheriganga, female $(51.25 \%)$ were more than Male $(48.75 \%)$ as shown in Table 6.

Table 6: Gender distribution of population in the study households on July 2016

\begin{tabular}{llll}
\hline Gender & \multicolumn{2}{c}{ Municipality } & Total \\
\cline { 2 - 3 } & $\begin{array}{l}\text { Birendra } \\
\text { Nagar }\end{array}$ & Bheriganga & \\
\hline Male & $172(50.74)$ & $156(48.75)$ & $328(49.77)$ \\
Female & $167(49.26)$ & $164(51.25)$ & $331(50.23)$ \\
\hline Total & $339(100.00)$ & $320(100.00)$ & $659(100.00$ \\
& & & ) \\
\hline
\end{tabular}

Figure in the parenthesis indicate percentage

\section{Size of Land Holding}

Land is the important component of any farming system. Land ownership within the agrarian economy of the study area provides a major source of income, which is an important natural asset that farmers have. Majority of the households have small category of land holding $(64.17 \%)$, followed by medium (18.33) and large (17.5\%) as shown in Table 7.

Table 7: Size of land holding in the study area on July 2016

\begin{tabular}{lllll}
\hline \multirow{2}{*}{$\begin{array}{l}\text { Land } \\
\text { size }\end{array}$} & $\begin{array}{l}\text { Land } \\
\text { category }\end{array}$ & \multicolumn{2}{c}{ Municipality } & Total \\
\cline { 3 - 4 } & & $\begin{array}{l}\text { Birendra } \\
\text { Nagar }\end{array}$ & $\begin{array}{l}\text { Bherig } \\
\text { anga }\end{array}$ \\
\hline$<0.5$ & Small & $27(45)$ & $\begin{array}{l}50 \\
(83.3)\end{array}$ & $\begin{array}{l}77 \\
(64.17)\end{array}$ \\
& & & $9(15)$ & 22 \\
$0.5-1$ & Medium & $13(21.7)$ & & $(18.33)$ \\
& & & $1(1.7)$ & 21 \\
& & $20(33.3)$ & & $(17.5)$ \\
\hline Total & & & 60 & 120 \\
& & $60(100.0)$ & $(100.0)$ & $(100.0)$
\end{tabular}

Figure in the parenthesis indicate percentage

\section{Average Size of Land Holding}

Average size of landholding was $1.02 \mathrm{Ha}$ in the study area (Table 8 ) with minimum of 0.1 ha and maximum of 3.03 ha in total.

Table 8: Average size of land holding of respondents on July 2016

\begin{tabular}{llll}
\hline Municipality & \multicolumn{3}{c}{ Land holding (ha) } \\
\cline { 2 - 4 } & Average & Minimum & Maximum \\
\hline Birendra Nagar & 0.72 & 0.03 & 1.7 \\
Bheriganga & 0.3 & 0.07 & 1.33 \\
\hline Total & 1.02 & 0.1 & 3.03 \\
\hline
\end{tabular}


Average Size of Rice Land Holding

Average size of rice cultivating land was 0.87 ha with minimum of 0.04 ha and maximum of 2.9 ha in total (Table 9).

Table 9: Average size of rice land holding of respondents on July 2016

\begin{tabular}{llll}
\hline Municipality & \multicolumn{3}{c}{ Land holding (ha) } \\
\cline { 2 - 4 } & Average & Minimum & Maximum \\
\hline Birendra Nagar & 0.66 & 0.01 & 1.7 \\
Bheriganga & 0.21 & 0.03 & 1.2 \\
\hline Total & 0.87 & 0.04 & 2.9 \\
\hline
\end{tabular}

\section{Farmer's Perception on Climate Change}

Awareness of Respondent on Climate Change in Study Area The frequency of extreme weather events such as drought, flooding, heat stress, landslide, hailstone and snowfall has been increasing (MoPE, 2004). The study revealed that 1.7 percentages of the respondents more clearly know about climate change, $20 \%$ respondents clearly know, $61.7 \%$ had little knowledge on climate change and $16.7 \%$ respondents had no idea about climate change as shown in Table 10.

Table 10. Awareness of respondents of the study area on climate change on July 2016

\begin{tabular}{lll}
\hline Awareness & Frequency & Percentage \\
\hline More clearly & 2 & 1.7 \\
Clearly & 24 & 20.0 \\
A little bit & 74 & 61.7
\end{tabular}

\section{Do not know}

20

\section{Source of Information}

During the study, Farmers expressed their response about climate change directly and indirectly, they relate it to their past experience, feeling and knowledge on rainfall, pattern, temperature and drought as compared to past. Respondents obtained information and experience on climate change by media $(43.43 \%)$ followed by self-experience $(36.36 \%)$, from local leaders and neighbor (13.13\%) and organization (7.07\%) as shown in Fig. 2.

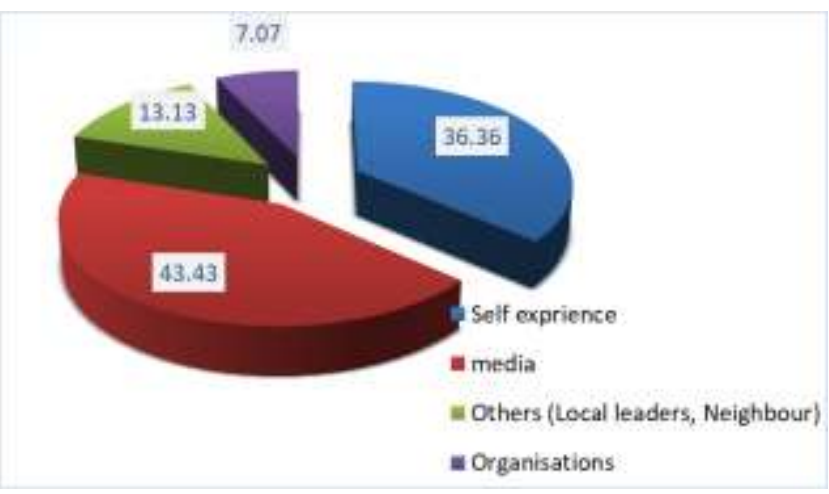

Fig 2. Source of information on climate change for farmers on July 2016

\section{Perception on Changing Temperature and Precipitation}

There is gradual increase in atmospheric temperature in different ecological zones of western development region of Nepal (Manandhar, 2009). Most of the respondents (82.5\%) felt the increase in temperature as compared to the past 10 years. $68.3 \%$ of the respondents felt the increase in hotter days, which was also proved by the increasing trend of maximum, average and minimum temperature from Surkhet meteorological station as shown in Fig. 4.

\section{口increased $\square$ Decrease $\square$ same}

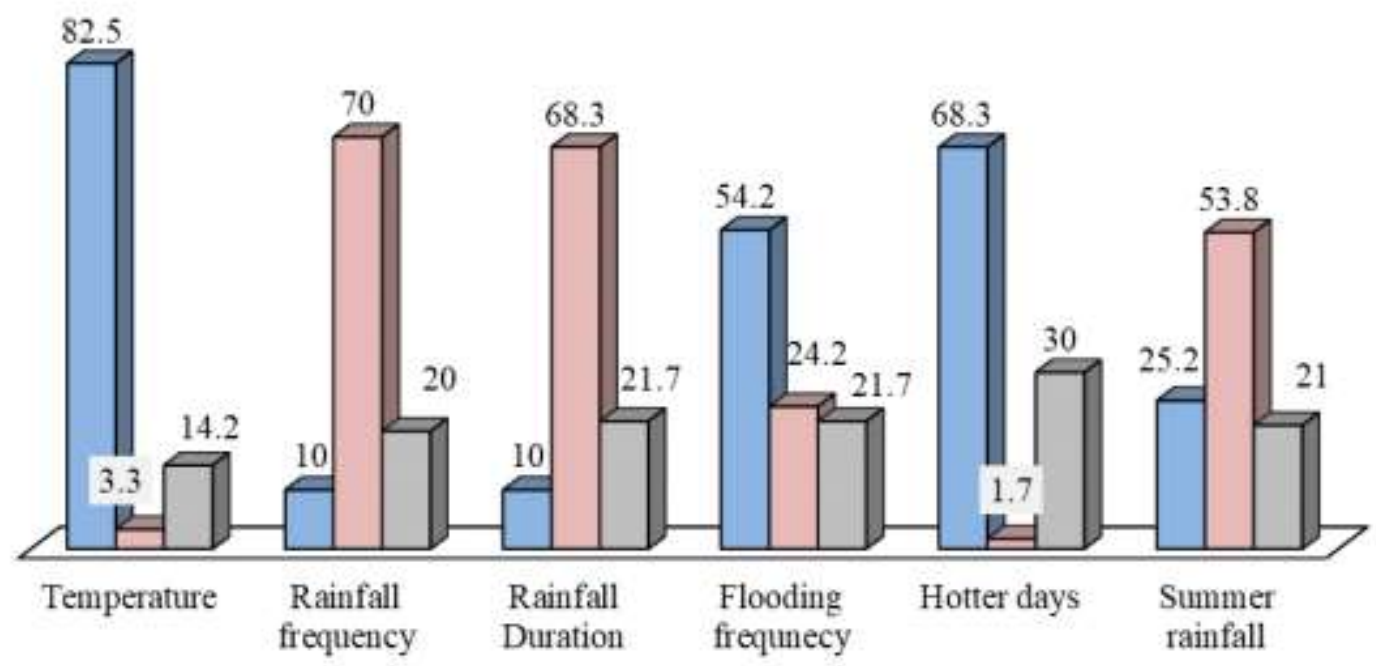

Fig. 3: Respondent perception on microclimate in the study area on July 2016. 
Farmer of the study perceived that there was decreased in precipitation as compared to the past. The majority of respondents reported decline in rainfall frequency $(70 \%)$, rainfall duration $(68.3 \%)$ and summer rainfall $(53.8 \%)$. The trend analysis of 35-year data obtained from metrological station, Surkhet also showed that the total rainfall was decreased by $3.77 \mathrm{~mm}$ per year as shown in Fig. 5. However, $54.2 \%$ respondents experience increased flooding frequency as compared to past in the study area. The study showed that Rainfall pattern was also experienced as inconsistent with the higher intensities of rain and less number of rainy days (Sapkota et al., 2010).

\section{Perception on Occurrence of Climatic Hazards}

The study revealed that the flood hazard is more experienced $(61.7 \%)$ in the study area followed by drought $(36.7 \%)$ as shown in Table 11.

\section{Respondent's Experience on Rice Cultivation Practices as Compared to Past Ten Year and Present Time}

Cultivation practices of rice experienced by farmers can be used to evaluate both climatic and non-climate factors affecting production and productivity of rice. Comparing the experience of farmers on rice transplanting and harvesting time, drought duration, insect pest infestation and yield variation ten years before and now is found in changing scenario. Majority of the respondents had transplanted $(57.5 \%)$ and harvested $(60.83 \%)$ rice earlier in the present time as compared to past. Although, there was decreasing trend as in time series analysis of pre-monsoon rainfall $0.6487 \mathrm{~mm}$ per year, due to use of electric motor, irrigation pump and dry nursery bed with early rice variety during nursery establishment and transplantation rice was earlier than before. The study revealed that $58.3 \%$ of the respondents had more yield than past ten years before; this may due to use of quality seed, hybrid varieties and better cultural practices as shown in Table 12 .

Table 11: Respondent's perception on climatic hazards on July 2016

\begin{tabular}{llc}
\hline Climatic hazard & \multicolumn{2}{c}{ Respondents perception } \\
\hline Flood hazard & Increased & $74(61.7)$ \\
& Decreased & $9(7.5)$ \\
& Same & $36(30)$ \\
Drought hazard & Increased & $44(36.7)$ \\
& Decreased & $6(5)$ \\
& Same & $70(58.3)$ \\
Landslide hazard & Increased & $16(13.3)$ \\
& Decreased & $5(4.2)$ \\
& Same & $99(82.5)$ \\
\hline
\end{tabular}

Figure in the parenthesis indicate percentage

Table 12: Respondents experience on rice cultivation practices comparing before ten year and now on July 2016

\begin{tabular}{lllll}
\hline $\begin{array}{l}\text { Rice cultivation practices as } \\
\text { compared to before 10 years }\end{array}$ & $\begin{array}{l}\text { Respondents } \\
\text { experience }\end{array}$ & $\begin{array}{l}\text { Birendra Nagar } \\
(\mathbf{n = 6 0})\end{array}$ & $\begin{array}{l}\text { Bheriganga } \\
(\mathbf{n = 6 0})\end{array}$ & $\begin{array}{l}\text { Total } \\
(\mathbf{N = 1 2 0})\end{array}$ \\
\hline \multirow{3}{*}{ Transplanting time } & Earlier & $36(60)$ & $33(55)$ & $69(57.5)$ \\
& Later & $2(3.3)$ & $5(8.3)$ & $7(5.83)$ \\
& Same & $22(36.7)$ & $22(36.7)$ & $44(36.67)$ \\
Harvesting time & Earlier & $37(61.7)$ & $36(60)$ & $73(60.83)$ \\
& Later & $2(3.3)$ & $5(8.3)$ & $7(5.83)$ \\
Rice yield & Same & $21(35)$ & $19(31.7)$ & $40(33.33)$ \\
& Earlier & $36(60)$ & $34(56.7)$ & $70(58.33)$ \\
\multirow{3}{*}{ Weed infestation } & Later & $10(16.7)$ & $22(36.7)$ & $32(26.67)$ \\
& Same & $14(23.3)$ & $4(6.7)$ & $18(15)$ \\
& Higher & $48(80)$ & $53(88.3)$ & $101(84.17)$ \\
Pest infestation & Lower & $11(18.3)$ & $7(11.7)$ & $18(15)$ \\
& Same & $1(1.7)$ & $0(0)$ & $1(0.83)$ \\
& Higher & $49(81.7)$ & $52(86.7)$ & $101(84.17)$ \\
\hline
\end{tabular}

Figure in the parenthesis indicate percentage 


\section{Trends Analysis of Annual Maximum, Minimum and Average Temperature}

Strong indicators of climate change scenario were detected in the climate variable data (temperature and rainfall) recorded by weather station nearby survey site over recent history (1996-2015) obtained from the metrological office Surkhet. Increase in annual maximum, minimum and average temperature were observed as shown in Fig. 4. The annual maximum temperature of this region has increased by $0.06^{\circ} \mathrm{C}$ per year. The annual minimum temperature of this region has increased by $0.03^{\circ} \mathrm{C}$ and annual average temperature increased by $0.006^{\circ} \mathrm{C}$ per year. The trends analysis strongly supports the farmer's perception that temperature was increasing. Increase in annual maximum temperature of this region is in line with national annual maximum temperature (DHM, 2017). The trend analysis of maximum temperature in Nepal found that the average annual warming between 1971 and 1994 was $0.06^{\circ} \mathrm{C} /$ year (Shrestha et al., 1999).

\section{Trend Analysis of Total Rainfall in Study Area}

Total precipitation of the study area was found to decreasing. The trend analysis of 35 year data showed that the total rainfall was decreased by $3.77 \mathrm{~mm}$ per year as shown in Fig. 5. The study on Rainfall trends analysis of thirty years (1971-2000) metrological data showed that the annual rainfall and number of rainy days were decreasing in month of July in Surkhet (Nayava, 2004).

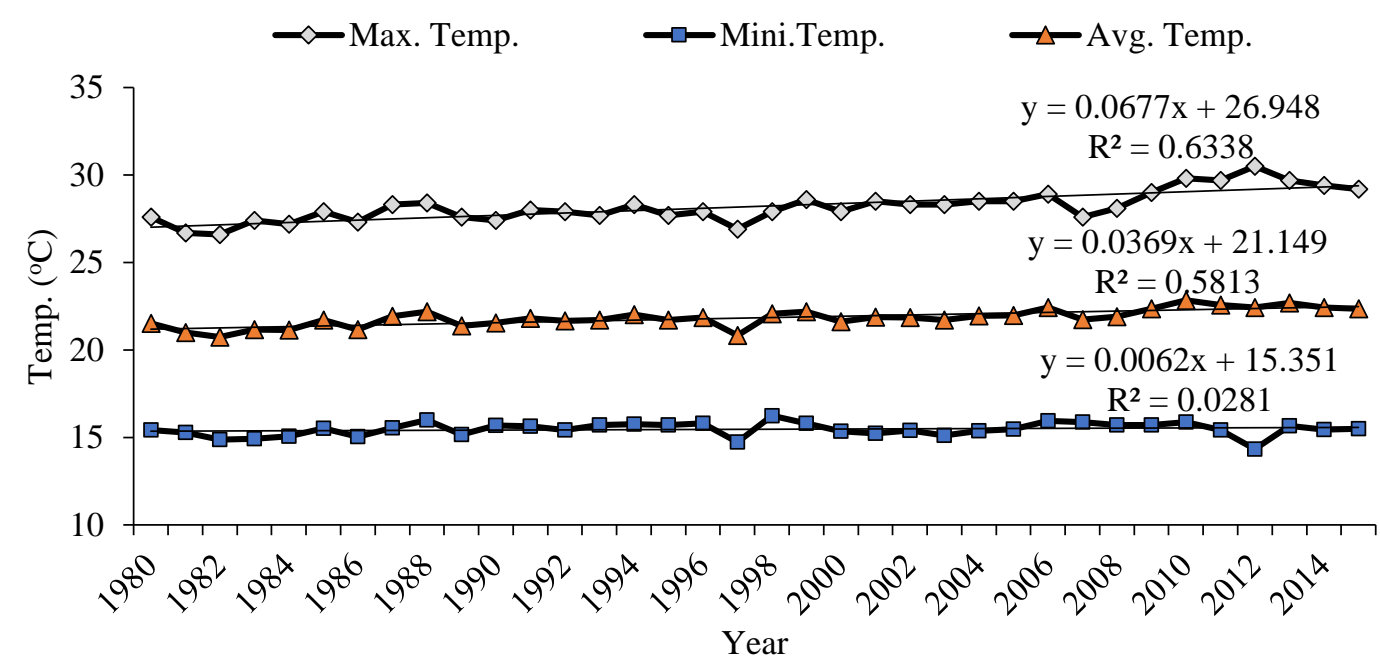

(Source: DHM. 2016)

Fig. 4: Average maximum, average minimum and mean annual temperature as recorded in Birendra Nagar metrological station, Surkhet (1980- 2015)

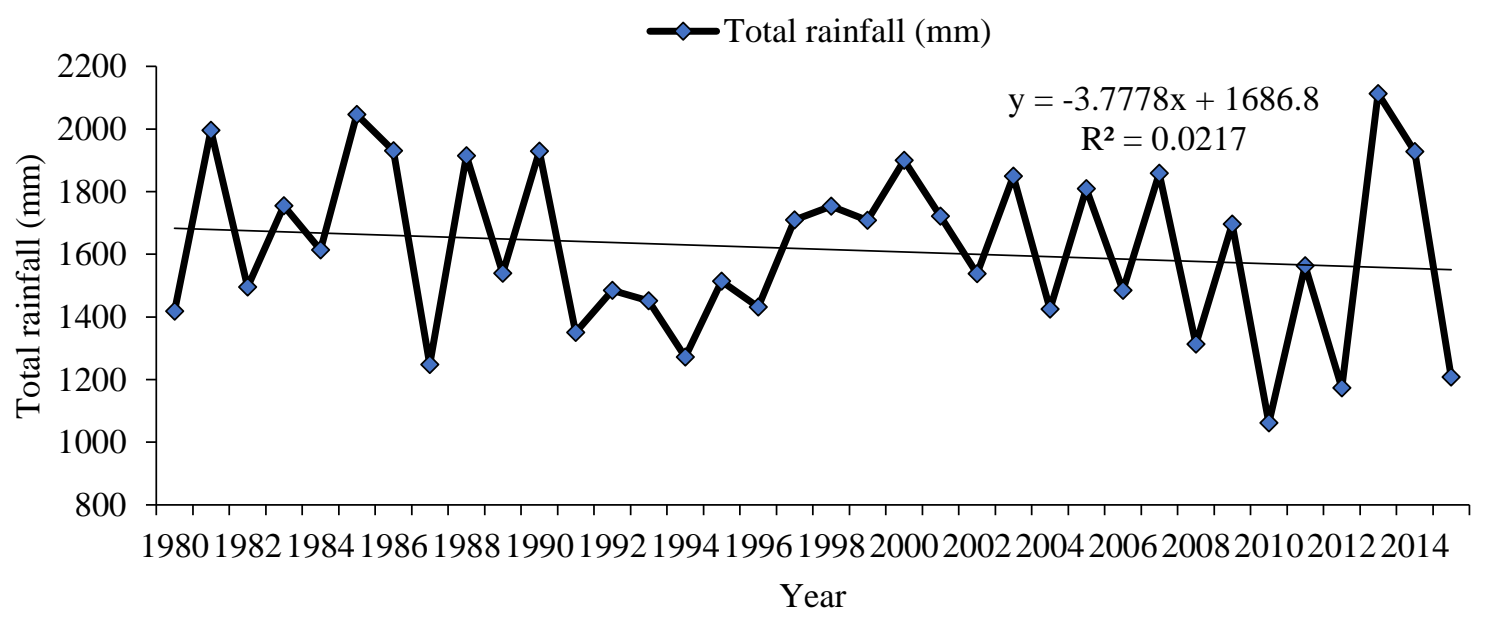

(Source: DHM, 2016)

Fig. 5: Total precipitation in Surkhet (1989-2015) 


\section{Pre-Monsoon, Monsoon and Post-Monsoon Rainfall \\ Trend}

The total pre-monsoon (March- May), monsoon (June to September) and post monsoon (October-November) rainfall trend were found to be varying across time horizon. The pre-monsoon rainfall showed decreasing trend by $0.64 \mathrm{~mm}$ per year, Monsoon rainfall increased by $0.051 \mathrm{~mm}$ per year and post monsoon rainfall decreased by $0.8 \mathrm{~mm}$ per year as shown in Fig. 6. The study on relationship between rainfall and rice yield from 1971 to 2015 showed that there is positive relationship between amount of monsoon rainfall and rice yield (Nayava, 2017). Thus, the increase in monsoon rainfall is better for rice yield. However, the nature of rainfall, its amount, Seasonal distribution and intensity, Frequency of occurrence, variability and areal variation are the major factors affecting agricultural potential (Nayava, 1980).

\section{Rice Growing Season Maximum, Minimum and Average Temperature Trend}

The trend analysis showed that the temperature of rice growing season is increasing trend. The maximum temperature was increased by $0.06^{\circ} \mathrm{C}$ per year while minimum and average temperature was increased by $0.009^{\circ} \mathrm{C}$ and $0.035^{\circ} \mathrm{C}$ per year respectively as shown in Fig. 7. The Study on trend analysis of annual mean temperature from 1973-2003 also showed a rising trend in Surkhet (Bhandari, 2013).

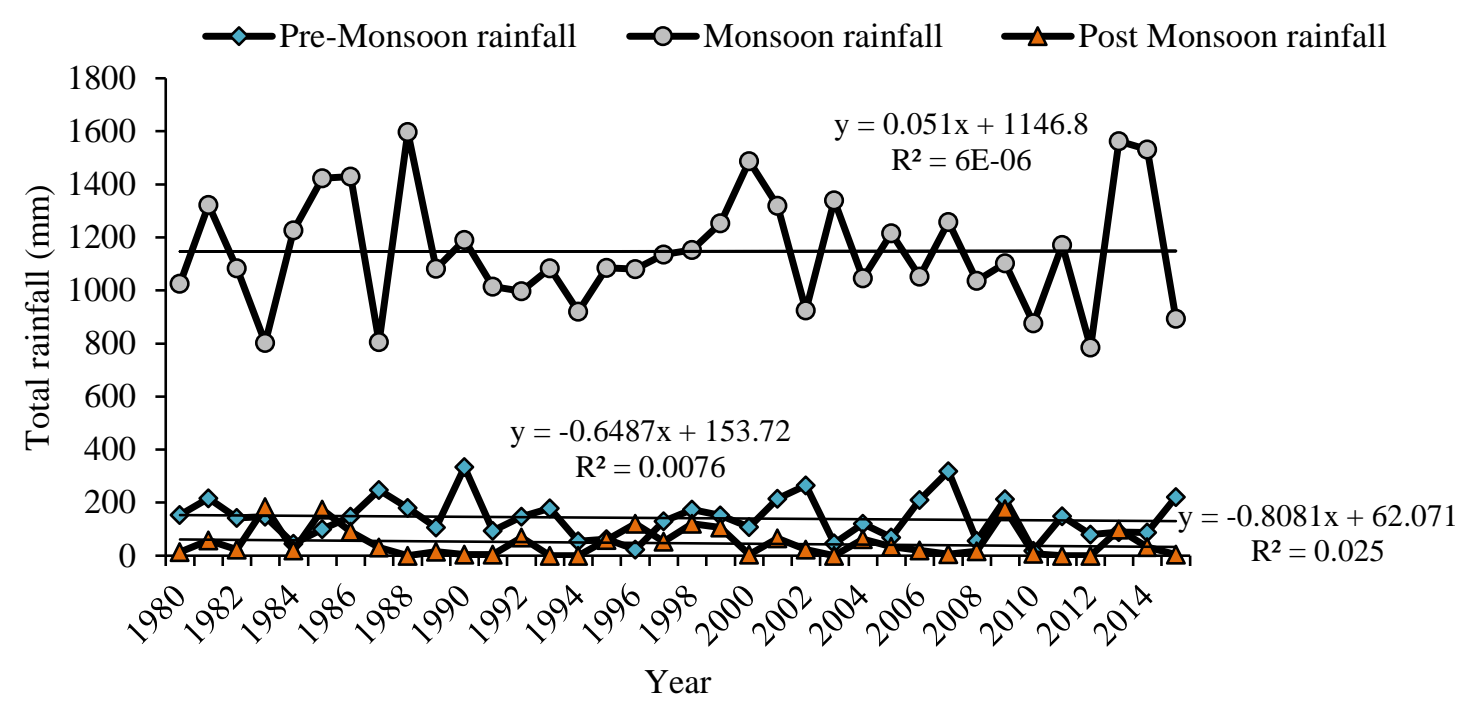

(Source: DHM, 2016)

Fig. 6: Pre monsoon, monsoon and post-monsoon rainfall in Surkhet (1980-1999)

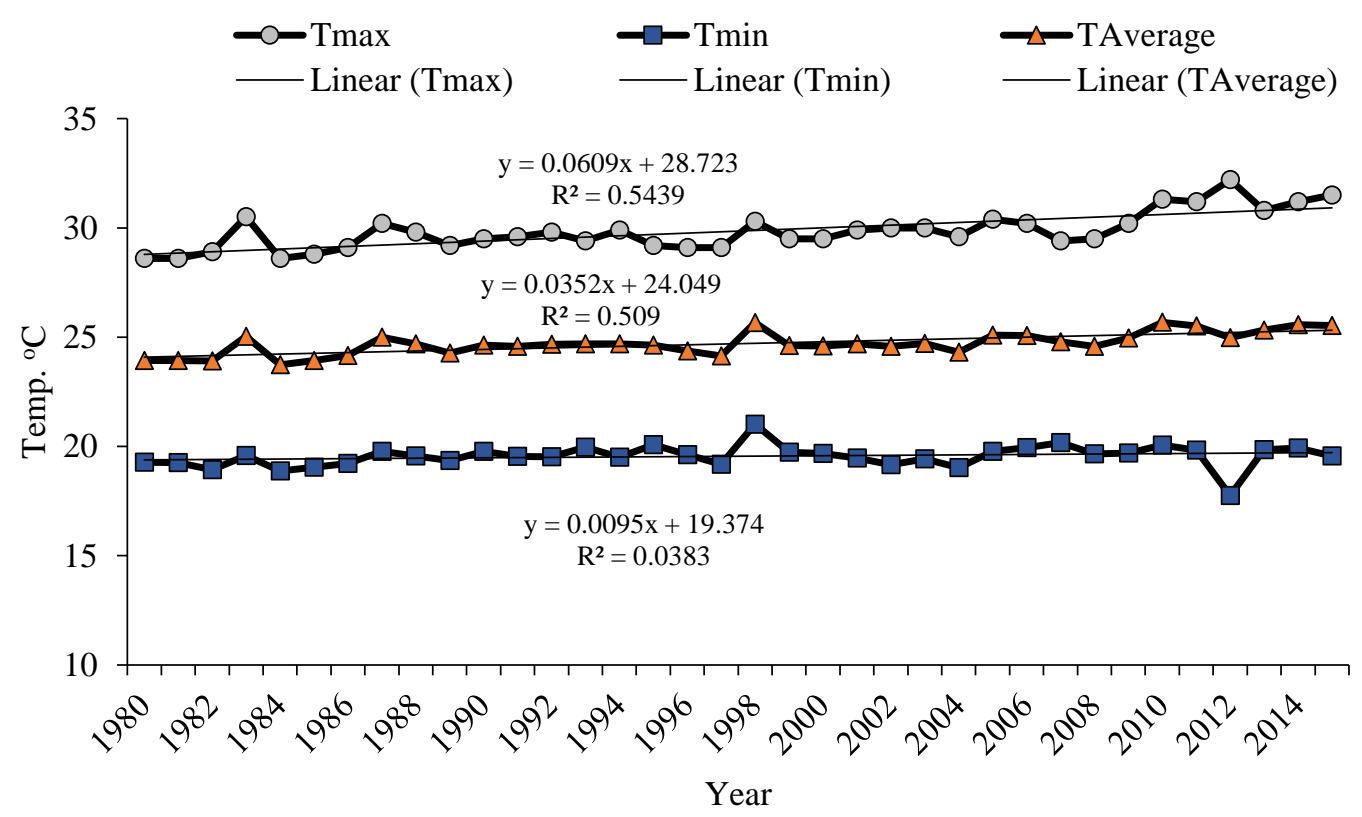

(Source: DHM, 2016)

Fig. 7: Rice growing season maximum, minimum and mean temperature in Surkhet (1980-2015) 


\section{Trend of Total Rainfall and Productivity of Rice}

The trends analysis of total seasonal rainfall (June to November) and productivity of rice showed that the productivity of rice had increased by 0.12 ton/ha, while the total seasonal rainfall was decreased by $13.01 \mathrm{~mm}$ per year over time period as shown Fig. 8. The study on trend analysis of rice yield with rainfall and temperature from 1975-2003 showed that yield of rice is increasing trends in Surkhet (Bhandari, 2013).

\section{Econometric Models}

Impact of Climate Variables on Area, Production and Yield of Rice

For the analysis of impact of climatic variables on the production and productivity of rice, 15 years, time series data of minimum temperature, maximum temperature, average temperature and seasonal rainfall of rainy season rice growing period of surveyed district were used. The mean area of rice cultivation was 13028 ha with productivity of 3 ton/ha. The rice growing period mean maximum temperature and minimum temperature found $30^{\circ} \mathrm{C}$ and $20^{\circ} \mathrm{C}$, respectively in Table 13 .
Climatic variables affecting the production and productivity of rainy season rice is presented in Table 14. The result showed that maximum temperature had significant positive effect on the production and productivity of rice. This indicates that, one unit increase in the maximum temperature will increase production of rice by 3278 Metric Ton. The temperature trends analysis from 1975-2003 showed that the average seasonal mean temperature from March-June and from July-November was $24.69^{\circ} \mathrm{C}$ and $23.7^{\circ} \mathrm{C}$, respectively in surkhet (Bhandari,2013). Increase in maximum temperature up to $29.9^{\circ} \mathrm{C}$ favors increase in paddy yield (Karn, 2014). The study on rice in NARC Tarahara, Nepal also showed that increase in maximum temperature up to $2^{\circ} \mathrm{C}$ and minimum temperature up to $1^{\circ} \mathrm{C}$ have positive impact on rice yield but beyond that temperature it has negative impact in rice production (Rai et al., 2014). Similar case was found by a research conducted at Hilly area of Nepal (Lalitpur) that increase in temperature favors rice production till $2^{\circ} \mathrm{C}$ (Ghimire et al., 2016).
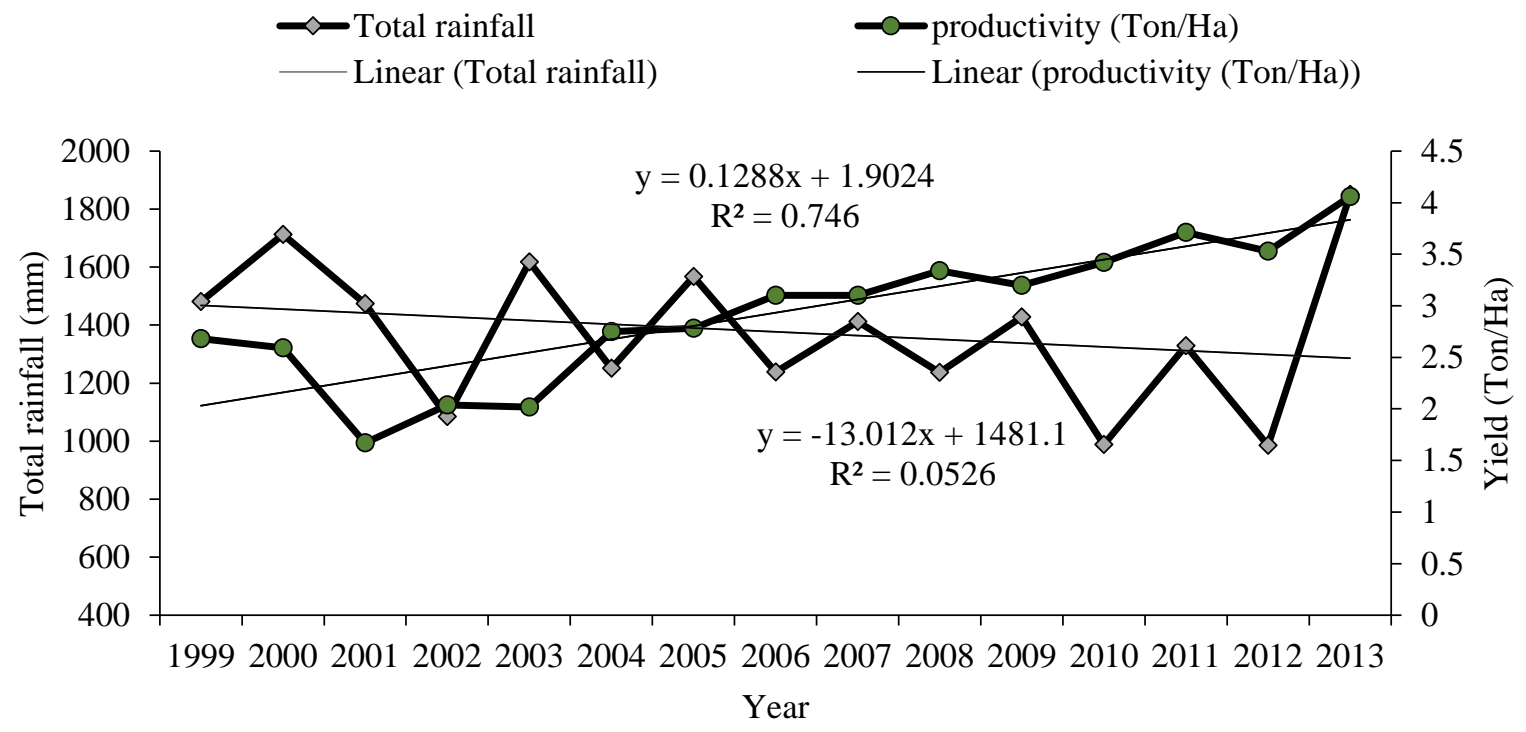

Fig. 8: Total rainfall and yield of rice (1999-2013)

Table 13: Statistical description of variables used to gauge impact of climatic variables on rice production (1999-2013)

\begin{tabular}{|c|c|c|c|c|c|}
\hline Variables & Description of variables & Mean & Maximum & Minimum & SD \\
\hline Area & Rice cultivating area in ha & 13028 & 14600 & 12327 & 871 \\
\hline Yield & Yield in metric ton/ha & 3 & 4 & 2 & 1 \\
\hline Production & Production in metric ton & 38825 & 59322 & 20673 & 11161 \\
\hline Rainfall & $\begin{array}{l}\text { Total seasonal rainfall (June to } \\
\text { November) in } \mathrm{mm}\end{array}$ & 1377 & 1850 & 985 & 254 \\
\hline T_Max & Maximum temperature (June to November) in ${ }^{\circ} \mathrm{C}$ & 30 & 32 & 29 & 1 \\
\hline T_Min & Minimum temperature (June to November) in ${ }^{\circ} \mathrm{C}$ & 20 & 20 & 18 & 1 \\
\hline T_Avg & $\begin{array}{l}\text { Average temperature (June to } \\
\text { November) in }{ }^{\circ} \mathrm{C}\end{array}$ & 24.91 & 25.7 & 24.3 & 0.39 \\
\hline
\end{tabular}


Table 14: Climatic variables affecting on production and yield of rice

\begin{tabular}{lllll}
\hline \multirow{2}{*}{ Variables } & \multicolumn{3}{c}{ Productivity } & Production \\
\cline { 2 - 5 } & Coeff. & Std. Err & Coeff. & Std. Err \\
\hline Total seasonal rainfall & 0.0000717 & 0.0006864 & 4.210388 & 10.34878 \\
T_max & $0.5779776^{* * *}$ & 0.2174659 & $11227.41^{* * *}$ & 3278.486 \\
T_min & 0.4471465 & 0.3029905 & 6189.412 & 4567.842 \\
\hline \multicolumn{1}{c}{ Note: ${ }^{* * *}$ and $^{* *}$ indicates significance at 1 percent and 5 percent level respectively }
\end{tabular}

Table 15: Farmer's adaptation practices on rice production on July 2016

\begin{tabular}{|c|c|c|c|c|}
\hline Adaptation practice & $\begin{array}{l}\text { Respondents } \\
\text { experience }\end{array}$ & $\begin{array}{l}\text { Birendra Nagar } \\
(n=60)\end{array}$ & $\begin{array}{l}\text { Bheriganga } \\
(\mathrm{n}=60)\end{array}$ & $\begin{array}{l}\text { Total } \\
(\mathrm{N}=120)\end{array}$ \\
\hline \multirow[t]{5}{*}{ Use of hybrid variety } & No use & $29(48.3)$ & $11(18.3)$ & $40(33.33)$ \\
\hline & US-312 & $29(48.3)$ & $23(38.3)$ & $52(43.33)$ \\
\hline & Shankar -360 & $1(1.7)$ & $17(28.3)$ & $18(15)$ \\
\hline & Gorkhnath -504 & $0(0)$ & $8(13.4)$ & $8(6.66)$ \\
\hline & No use & $34(56.7)$ & $44(73.3)$ & $78(65)$ \\
\hline Use of drought resistant & Sukkha-1 & $18(30)$ & $9(15)$ & $27(22.5)$ \\
\hline \multirow[t]{3}{*}{ Variety } & Sukkha-2 & $7(11.7)$ & $6(10)$ & $13(10.83)$ \\
\hline & Sukkha-3 & $1(1.7)$ & $1(1.7)$ & $2(1.67)$ \\
\hline & No use & $42(70)$ & $54(90)$ & $96(80)$ \\
\hline \multirow[t]{3}{*}{ Use of flood tolerant } & Swarnasub-1 & $15(25)$ & $3(5)$ & $18(15)$ \\
\hline & Swarnasub-2 & $3(5)$ & $3(5)$ & $6(5)$ \\
\hline & No use & $37(61.7)$ & $44(73.3)$ & $81(67.5)$ \\
\hline \multirow{4}{*}{ Local variety } & Dadamansuli & $23(38.3)$ & $10(16.7)$ & $33(27.5)$ \\
\hline & Thapajini & $0(0)$ & $2(3.3)$ & $2(1.67)$ \\
\hline & Gude & $0(0)$ & $4(6.7)$ & $4(3.33)$ \\
\hline & Use of electric motor & $37(63.8)$ & $5(8.6)$ & $42(35)$ \\
\hline \multirow{3}{*}{$\begin{array}{l}\text { Nursery preparation, } \\
\text { irrigation }\end{array}$} & Dry seed bed & $10(17.2)$ & $8(13.8)$ & $18(15)$ \\
\hline & irrigation channel & $10(17.2)$ & $45(77.6)$ & $55(45.83)$ \\
\hline & Manually & $59(98.3)$ & $60(100)$ & $119(99.17)$ \\
\hline \multirow[t]{2}{*}{ Weed management } & Chemical & $1(1.7)$ & $0(0)$ & $1(0.83)$ \\
\hline & Chemical & $53(88.3)$ & $33(55)$ & $86(71.67)$ \\
\hline \multirow[t]{2}{*}{ Pest management } & IPM & $2(3.3)$ & $0(0)$ & $2(1.67)$ \\
\hline & Organic & $5(8.3)$ & $27(45)$ & $32(26.67)$ \\
\hline Know about Crop & No & $34(56.7)$ & $39(65)$ & $73(60.83)$ \\
\hline \multirow[t]{2}{*}{ insurance } & Yes & $26(43.3)$ & $21(35)$ & $47(39.17)$ \\
\hline & No & $54(90)$ & $58(96.7)$ & $112(93.33)$ \\
\hline \multirow[t]{4}{*}{ Crop insurance } & Cereal (Rice) & $0(0)$ & $1(1.7)$ & $1(0.83)$ \\
\hline & $\begin{array}{l}\text { Vegetables (Cauli flower, } \\
\text { tomato, cucumber) }\end{array}$ & $4(6.7)$ & $1(1.7)$ & $5(4.17)$ \\
\hline & Livestock (Cow) & $1(1.7)$ & $0(0)$ & $1(0.83)$ \\
\hline & Bee & $1(1.7)$ & $0(0)$ & $1(0.83)$ \\
\hline
\end{tabular}

Figure in the parenthesis indicate percentage

\section{Farmer's Adaptation Practices to Changing Climate on Rice Production}

The farmers having low income and low adaptive capacity are hit hard by climate change (Regmi et al., 2009). Local knowledge and innovations are important insights to solve the big problems so they should be promoted instead of being ignored or subsided (Krone et al., 2006). Majority of the respondents used rice hybrid variety US-312 (43.33\%) followed by Shankar-360 (15\%) and Gorakhnath (6.66\%). The study showed increase in disease, pest and weed infestation in present year as compared to past ten years before. Farmers of study area just started to adopt different drought resistant, flood resistant rice varieties to cope with the climate change adversities. Out of the 120 households,
22.5 percent farmers used drought resistant rice variety Sukkha dhan-1, followed by Sukkha dhan-2 (10.83\%) and sukkah-3 (1.67\%). About 20 percent farmers use flood resistant variety; $15 \%$ of farmers used Swarna sub-1 and 5 $\%$ of farmers used Swarna sub-2. In the study area, 45.83 $\%$ of farmers used irrigation channel during nursery preparation, $35 \%$ of farmers used electric motor pump for irrigation. Similar practices were adopted by farmeres such as; changing sowing/planting date of crop, use of improved varieties, using more chemical fertilizer and using pest management practices coping with adverse climatic conditions in Bardiya district (Sharma et al.,2020). Crop insurance is one of the adaptation practices to climate change (Table 15). 


\section{Conclusion}

Most of the farmers in the study area perceived climate change at present time in terms of change in rainfall pattern, rainfall duration, rainfall intensity, rainfall frequency, onset of monsoon, increase in climatic hazard and changes in summer temperatures in terms of hotness. Commonly, drought led to low crop yield especially in the rain-fed rice farming system. The flooding cause damaged and loss of standing crop in field by buried, sedimentation and increase in pest infestation. Moreover, flooding also cause loss of human live, shelter and affect the livelihood. The study was carried out to assess the climate change impact on rice production, perception of famers to climate change and local adaptation strategies in response of changing climate. Surkhet district of Mid-western inner terai region was taken in consideration for the proposed study. Two municipalities from the district were purposively selected. Altogether, 120 household, 60 from each municipality, were selected by simple random sampling method. Primary data were collected by administering the questionnaire survey, focus group discussion, key informant interview and direct observation. Secondary data related to climate were obtained from DHM, Mid and far-western regional climate office, Surkhet and data related to rice production obtained from DoA and DADO-Surkhet.

The study population was dominated by Janajati (47.5\%) mainly Tharu community with an average family size of 5.67, which is little more than national status. Agriculture including livestock was major occupation $(86.6 \%)$ of the respondents with average landholding size of 1.02 ha. Total monsoon rainfall, minimum temperature and maximum temperature were increasing by $0.051 \mathrm{~mm}, 0.03^{\circ} \mathrm{C}$ and $0.06^{\circ} \mathrm{C}$ per year respectively in Surkhet, over the times as perceived by the farmers. But the mean annual rainfall and total rainfall were decreasing by $0.351 \mathrm{~mm}$ and $3.77 \mathrm{~mm}$ per year respectively. There was increasing trends of disease pest infestation as perceived by farmers.

The optimum temperature range for rice growing period is $22-30^{\circ} \mathrm{C}$. The regression analysis for independent (climatic variable) and dependent variables i.e. \{productivity (MT/hac) and production (MT) \} showed that the average maximum temperature has positive effect on yield and production. However, since the current average temperature for 1999 to 2008 is already $30.8^{\circ} \mathrm{C}$. It is expected that rice yields are negatively affected by increase in daily maximum temperature.

The increase in monsoon rainfall is favorable for the increase in rice yield but the variation in precipitation cause flooding and drought occurred during rice production leads to reduction in production. Rice productivity and production with climatic variables shows that productivity and production are increasing due to increase in maximum temperature but it will be desirable that farmers are sensitized about climate change, its impact, and its adaptation to be prepared for future climate extreme events.

The increase in disease, pest infestation is major problems for farmers. Farmers were practicing different coping and adaptation strategies in their farm based upon their experience to tackle with changing climate. But there should be promotion of local and indigenous adaptation practices followed by farmers which are economically feasible ecologically sound and environmentally acceptable. Changing climate under rainfed condition was affecting the normal cropping calendar and crop rotation as compared to the past by the farmers. Changes in cropping calendar hinder the crop growth leading poor yields. Farmers used a range of adaptation strategies to cope and adapt to climate effects. The strategies used for adaptation included afforestation, change in planting dates, switching to irrigation farming, construction of irrigation channel, plastic pond, water harvesting tank, practicing mulching, shifting to cropping system, crop diversification and engagement in non-farming activities. Despite being willing to use the coping and adaptation strategies, most of the smallholder farmers faced challenges such as lack of capital, adaptation knowledge and water for irrigation.

\section{Authors' Contribution}

This work was carried out in collaboration with all authors. BB Khadka, H Sharma and AP Subedi conceptualized and designed the research plan. BB Khadka acquired of the Data, performed the statistical analysis and interpretation, wrote the first draft of manuscript and Critically revised the manuscript. SC Dhakal guided the statistical analysis and manuscript writing. All the authors read, finalized and approved the final manuscript.

\section{Conflict of Interest}

The authors declare that there is no conflict of interest with present publication.

\section{References}

Bhandari G (2013) Trends in seasonal precipitation and temperature: A review In Doti and Surkhet Districts of Nepal. International Journal of Environment 2(1): 269-279.

CBS (2011) Statistical year book Nepal. Central Bureau of Statistics, National Planning Commission, Kathmandu, Nepal.

DADO (2015) Annual Agriculture Development Program and Statistics: District Agriculture Development Office, Surkhet.

DHM (2016) Hydrological Records of Nepal. Department of Hydrology and meteorology, Kathmandu, Nepal.

DHM (2017) Observed Climate Trend Analysis in the Districts and Physiographic Regions of Nepal 
(1971-2014). Department of Hydrology and Meteorology, Kathmandu.

Ghimire A, GC YD \& Baniya B (2016) Impact of elevated temperature on rice productivity: A case of Lalitpur, Nepal. Nepal Journal of Environmental Science 4:19-22.

IPCC (2007) Climate Change 2007. In: Solomon S, Qin D, Manning M, Chen Z, Marquis M, Averyt K, Tignor $\mathrm{M}$ and Miller HL (eds.). The physical science basis. Contribution of Working Group I to the Fourth Assessment Report of the Intergovernmental Panel on Climate Change. Cambridge University Press, Cambridge, United Kingdom and New York, NY, USA, 996p.

Karn PK (2014) The impact of climate change on rice production in Nepal. SANDEE; 2014.

Krone A, Waters-Bayer A, Letty B, Food FA, Learning PP, Action PM, Micro MA, Micro MF, Xaba MM (2006) Feasibility study in to the introduction of a local innovation support facility in to Okhahlamba district, Kwazulu-Natal, South Africa PROLINNOVA-South Africa 12(4): 611-629.

Malla G (2008) Climate change and its impact on Nepalese agriculture. The Journal of Nepalese Agriculture 9: 62-71.

Manandhar S (2009) Perception of and adaptation to climate change by farmers in different ecological zones of the western development region of Nepal. Thesis, M.Sc. Asian Institute of Technology (AIT), School of Environment Resources and Development, Thailand.

Maraseni TN (2012) Climate change, poverty and livelihoods: adaptation practices by rural mountain communities in Nepal. Environmental science \& policy 21: 24-34.

MoAD (2012) Statistical Information on Nepalese Agriculture (2011/2012). Government of Nepal, Ministry of Agricultural Development, AgriBusiness Promotion and Statistics Section, Singha Durbar, Kathmandu, Nepal.

MoAD (2014) Statistical Information on Nepalese Agriculture (2013/2014). Government of Nepal, Ministry of Agricultural Development, AgriBusiness Promotion and Statistics Section, Singha Durbar, Kathmandu, Nepal.

MoE (2010) National Adaptation Programme of Action (NAPA). Government of Nepal, Ministry of Environment, Singha Durbar, Kathmandu.
MoPE (2004) Initial National Communication to the Conference of Convention on Climate Change. Ministry of Population and Environment, Kathmandu.

Nayava JL (1980) Rainfall in Nepal. Himalayan Review 12: $1-18$.

Nayava JL (2004) Temporal variations of rainfall in Nepal since 1971 to 2000. Journal of Hydrology and Meteorology 1: 24-33.

Nayava JL (2017) Monsoonal Rainfall and its Impact on Rice Production in Nepal. Rice Science and Technology in Nepal. Crop Development Directorate (CDD) and Agronomy Society of Nepal (ASoN), 497-506.

Oli BN \& Shrestha K (2009) Carbon status in forests of Nepal: an overview. Journal of Forest and Livelihood 8(1): 62-66.

Panthi J, Aryal S, Dahal P, Bhandari P, Krakauer NY \& Pandey VP (2016) Livelihood vulnerability approach to assessing climate change impacts on mixed agro-livestock smallholders around the Gandaki River Basin in Nepal. Regional Environmental Change 16(4): 1121-1132.

Rai YK, Ale BB, \& Alam J (2009) Impact assessment of climate change on paddy yield: A case study of Nepal Agriculture Research Council (NARC), Tarahara, Nepal. Journal of the Institute of Engineering 8: 147-167.

Regmi BR, Paudyal A \& Bordoni P (2009) Climate change and agrobiodiversity in Nepal: Opportunities to include agrobiodiversity maintenance to support Nepal's National Adaptation Programme of Action (NAPA). LI-BIRD: Pokhara, Nepal.

Sapkota S, Paudel MN, Thakur NS, Nepali MB \& Neupane $\mathrm{R}$ (2010) Effect of climate change on rice production: A case of six VDCs in Jumla district. Nepal Journal of Science and Technology 11: 57-62.

Sharma H, Chapagain S \& Marasini S (2020) Impact of climate change on paddy-wheat production and the local adaptation practices by farmers of Bardiya, Nepal. International Journal of Agriculture Forestry and Life Sciences 4(1): 137-146. Retrieved from http://www.ijafls.org/en/issue/51802/728966

Shrestha AB, Wake CP, Mayewski PA \& Dibb JE (1999) Maximum temperature trends in the Himalaya and its vicinity: an analysis based on temperature records from Nepal for the period 1971-94. Journal of climate 12(9): 2775-2786. 